\title{
The Strategic Role of Teacher Training Institute (LPTK) In Building Professional Teacher
}

\author{
Fathur Rokhman $^{\text {a }}$ Farid Ahmadi ${ }^{\mathrm{b}}$, Ratna Dewi Kusumaningtyas ${ }^{\mathrm{c}}$ \\ Universitas Negeri Semarang \\ Corresponding e-mail: afathurrokhman@mail.unnes.ac.id, bfarid@mail.unnes.ac.id, \\ cratnadewi.kusumaningtyas@mail.unnes.ac.id
}

\begin{abstract}
It is inevitable that professional teacher will not be realized without the contribution of Teacher Training Institute (LPTK). Therefore, LPTK holds a critical role which they do not merely have to award the teacher-to be with certificates along with the title of "Bachelor of Education", but also assure the professionalism of the teachers. Consequently, LPTK should be a multifunction institution which has well-structured-system, clear vision and mission, as well as the eligible stakeholder to build the Human Resources that is ready to develop the nation's intellectual life through its graduates. Furthermore, LPTK should move out from their comfort zone and start to elevate their quality according to the content of Higher Education Act year 2012 and maximize the implementation of Indonesian Qualifications Framework (KKNI) as well as National Standard for Higher Education (SNPT). Those are inevitable since the challenge faced by teachers/lecturers in this millennial era are becoming more complex along with the implementation of Curriculum 2013 which the target should have been achieved by 2020 . One of the indicators of teacher professionalism is obtaining the teaching certification from Education and Training for Teaching Profession (PLPG), Professional Teacher Training Program (PPG), and other similar programs. Unfortunately, the existing amount of such teacher is incompatible with the real condition, as in terms of quantity, we are lack of teachers. According to the data from PGRI (Indonesian Teacher's Union) in 2017, there are 155,048 redundant teachers in the whole nation. Yet if we look at the smaller scale, in school, we have insufficient permanent teacher. Based on Dapodik 2016, there are 550,604 more teachers needed in Elementary, Junior High, and Senior High School. While in Vocational High School, there are 91,000 teachers needed. The role of LPTK in conducting both programs, PLPG and PPG, is a strategic plan in building professional teachers who are capable to achieve the objective of national education. According to several related research, one of LPTK such as Universitas Negeri Semarang has successfully conducted both programs for five years in order to produce professional teachers. The data acquired from the Department of Information and Communication Technology at Universitas Negeri Semarang in 2017 showed that PLPG and PPG are the eminent program in preparing professional teachers that UNNES has always been trusted by the government as the host LPTK to conduct both program.
\end{abstract}

Keyword: LPTK, professional, teacher, teacher training program

\section{INTRODUCTION}

It is inevitable that professional teacher will not be realized without the contribution of Teacher Training Institute (LPTK). Therefore, LPTK holds a critical role which they do not merely have to award the teacher-to be with certificates along with the title of "Bachelor of Education", but also assure the professionalism of the teachers. Consequently, LPTK should be a multifunction institution which has wellstructured-system, clear vision and mission, as well as the eligible stakeholder to build the Human Resources that is ready to develop the nation's intellectual life through its graduates.

Since the Teacher and Lecturer Law (UUGD) are taken in effect in 2005, the interest of scholar in LPTK is elevated. Not to mention, the regulation of increasing the certification allowance for teachers attracts more attention of the undergraduates. That's why, many of the study programs in LPTK placed in the top rank among other programs during the Nationwide University Admission. Even though this can be 
considered as a new routine and "pride" of LPTK, yet this is also another challenge for this institution to improve its quality.

The policy of increasing the certification allowance is aimed to raise the teachers' motivation in teaching. This shows that the government's appreciation towards education and teaching is improving. Previously, the payment awarded for teachers were considered low that even insufficient to fulfill their daily needs. Even so, the universities - both private and state universities, especially LPTK, had successfully graduated hundreds of students specialized in educational profession. Ironically, only some of them can be accepted in educational institution for the imbalance quantity of school and teacher.

In order to fix the conditions above, LPTK should move out of their "comfort zone" by improving their quality in accordance with the content of Higher Education Act year 2012 and maximize the implementation of Indonesian Qualifications Framework (KKNI) as well as National Standard for Higher Education (SNPT). Those are inevitable since the challenge faced by teachers/lecturers in this millennial era are becoming more complex along with the implementation of Curriculum 2013 which the target should have been achieved by 2020 . Other challenges are the implementation of National Literary Movement (GLN) and School Literary Movement (GLS).

Based on the Regulation of Ministry of Education and Culture of the Republic of Indonesia (Kemendikbud) Number 160 Year 2014 about the enactment of Curriculum 2006 and Curriculum 2013 (K13) in article 4 that says: the educational unit of elementary and junior high could only implement Curriculum 2006 till the education year of 2019/2020. This policy allows the schools that has not ready to implement K13, can stick to Curriculum 2006 while preparing themselves to implement K13 optimally by 2020 . As the initial step in preparing the complete implementation of K13, a Technical Guidance was conducted to train the teachers and educational staffs in schools as well as other stakeholders involved in education.

Curriculum 2013 has been implemented continuously in 2014, 2015, 2016 and the rate of its application is gradually increased through the years $6.25 \%, 18.75 \%$, and $25 \%$ for the elementary school throughout Indonesia. Therefore, by 2016 , there have been 37,034 schools implement K13. In education year $2017 / 2018$, there are $35 \%$ of elementary school or 52,772 schools targeted to apply K13 that makes $60 \%$ of the overall elementary school managed to implement Curriculum 2013. In the attempt to support the implementation of K13 in elementary school, all the stakeholders that involve in guiding and supervising the implementation in each institution such as head master, teachers, and supervisor should undergo trainings related to K13. The knowledge and skill all the instrument of the curriculum shall go hand in hand with the statutory regulations andn policies (Kemendikbud, 2017:1).

In the other hand, government must encourage the educational institution either under Ministry of Education and Culture or Ministry of Research, Technology, and Higher Education to adjust the competency standard of graduates to the existing International standard. Within the era of ASEAN Economic Community (AEC), all the educational institutions do not have any other choice other than level up their quality that all the systems are revised. All teachers are demanded to be graduates and lecturers are demanded to be doctors in all over ASEAN. Therefore, this the moment when the role of LPTK needs to be strengthen for their strategic position in producing professional teachers for the sake of human resource development within this complex day.

ASEAN Economic Community presents various challenges and problems to be solved that knowledge, technology, and human resources are the key factors in determining the competitiveness of one nation. Samani (2008) stated that the power of a country in this global word are indicated from these factors: (1) innovation and creativity (45\%), (2) networking $(25 \%)$, (3) technology $(20 \%)$, (4) natural resources $10 \%$. A country with numerous natural resources is incapable to compete in the global word without the skilled human recourses. Other factors such as innovation and creativity, networking, and technology will also be acquired through prominent human recourses. In short, the quality development of the nations is essential in improving the competitiveness among the global word.

Educational sector, thus, becomes the key factor in improving the quality of the nations in this global era for educations is the main approach in developing the human recourses. 
Basically, education is a process to equip students with skill, critical thinking, adaptability, good moral commitment, and the ability to mingle with the multicultural society. Particularly, AEC has become the new challenge for education world. Educational institutions are expected to graduate competitive generations. In the implementation, education involves three components: teachers, curriculum, and facilities. Among the three components, teachers are the key that identify the quality of educations as they are the center as well as the source of education. Teachers hold substantial role as their duty is not only teaching the students but also becoming the role model for the students. An exceptional teacher will be able to optimize the existing facilities to endeavor the targeted competence of the students in accordance with the curriculum. Constitution No 202003 about National Education System and Constitution No, 142005 about Teacher and Lecturer has set a standard that the quality improvement for teachers is the capital to elevate the quality of education as it will consequently improve the teaching quality, learning innovation and high-tech learning media.

Well-qualified teachers are those who have fulfilled the criteria as professional educators. According to Government Regulation No. 74 2008 , teacher is defined as professional educator with the main obligations, such as educate, teach, guide, direct, train, assess, and evaluate the pupils in early childhood education, formal education, elementary and high school education. Unfortunately, the quality of teachers in Indonesia is relatively low according to the recent data collected. Based on the result of Teacher Competency Test (UKG), only 192 teachers out of 1.6 million who obtained the score above 90. Additionally, in terms of students' score, the Indonesian junior high school students' achievement in Tends International Mathematics and Science Study (TIMMS) 2011 is considered low compared to the neighboring countries. As comparison, the achievements of students in Singapore is $84 \%$ (the highest), Korea and Japan 81\%, Australia $71 \%$, US $69 \%$, Malaysia $43 \%$, South Africa $30 \%$, Indonesia $26 \%$, and Ghana $21 \%$ (lowest). Besides, fresh graduates of LPTK are known to have several weaknesses: 1) low English proficiency, 2) low in leadership, team-work, communication, critical thinking, and skill in IT,
3) Enough technical skill but low thinking skill, 4) low in written and oral communication, confidence, and moral value. This situation proves that it is such an urgent issue to prepare professional teachers and improve the quality of existing teachers in order to provide prominent and competitive human recourses.

LPTK as the institutions that produce professional teacher is responsible to not merely build professional teacher, but also qualified enough to sustain in the era of AEC. Because of the low quality of our current teachers and the graduates of LPTK along with the increasing demand upon education and the improvement of human recourses, government pay more and more attention to teachers and LPTK. Without qualified teachers, the available human recourses and the upcoming generation will not be able to compete in the era of globalization. Thus, since 2009, the government put education as the priority sector to be developed in hope that it would result to more qualified human resources for the sake of better national development. The steps taken by our government to rebuild our education was vary, started from increasing the quality and professionalism of teachers, fixing the learning facilities, assuring the teachers' prosperity, up to providing accessible and cheap course book. As the starting point of teacher-maker, LPTK, also gained the attention from the government and implement the program of LPTK revitalization. This program aimed to improve the quality of LPTK for qualified LPTK will produce professional and qualified teachers/graduates.

In order to improve the quality of LPTK graduates, it is necessary to develop a revitalization model for LPTK that can be a national reference. According to Constitution No. 142015 about the role of LPTK, revitalization of LPTK involve several main elements (Picture 1), those are:

1. Teacher Professionalism Training Program

2. Institution Licensing

3. Specific and visionary curriculum

4. Supporting Facilities

5. Modern Management System

6. Lab-School and partnering school

7. Academic culture to construct professional teacher 


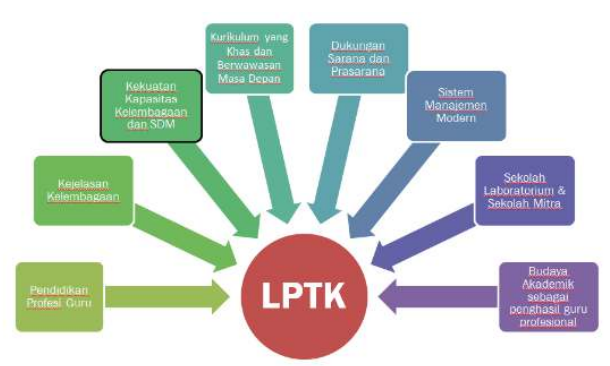

Figure 1. Main Elements of Revitalization of LPTK. Source: The result of Teacher Education Summit, 2012

\section{DISCUSSION}

\subsection{The Condition of LPTK and Teacher in the Millennial Era}

LPTKs in Indonesia hold different system from one and another, there are state-owned LPTK and private LPTK. Besides, there are also LPTK who works under the Coordination of Private Universities (Kopertis) along with the Ministry of Research, Technology, and Higher Education (Kemenristek Dikti) and/or universities that work under the Coordination of Private Universities (Kopertis) and/or the Ministry of Religious Affairs (Kemenag). This system is so far still out of people's concern even though this is actually the basic of LPTK framework.

Kemenristek Dikti leads both the category of State University (PTN) or Private University (PTS). While Kemenag supervise State Islamic University (PTAIN) and Islamic University (PTAI). Even though they have different head, during the nation-wide university admission, all of them are included in the home base of Kemenristek Dikti.

Throughout the year, PTS in Indonesia keep improving themselves. More and more PTS are founded in Indonesia, either under the supervision of Kemenristek Dikti or Kemenag, especially in Central Java Province and Special District of Jakarta. The growing and improvement of PTS is a kind of progress in Indonesian education sector. Even so, the aspects to be paid attention on are not only about the operational, administrative, and procedure, but it is also about the quality, reputation, and also the accreditation. This quality can be seen from the academic, judicial, financial, and facilities. In terms of Human Resource Development, the most essential sector is the academic sector. This is because universities are expected to do Tri Dharma of Higher Education, those are education, research, and social work. Therefore, the next question would be, are the numerous

\subsection{The Phenomena of Unqualified University}

In terms of Academic, both PTN and PTS are similar as they both conduct education based on the Constitution Number 12 Year 2012 about Higher Education. The aspects to be kept in mind are the status and quality for, indeed, there are so many campuses founded in Indonesia but not all of them are obtaining the license from Kemenristek dikti. Consequently, the certificate belonged to the graduates are not being acknowledged that the reputation of the campus becoming worse.

Kemenristek dikti had taken several actions towards bad reputation-campuses. In 2015, there are 243 universities being nonactivated due to several problems (Detik.com, 1/10/2015). National Accreditation Board for Higher Education (BAN-PT) in 2015 recorded that there are 46 study program which the accreditations have been expired (Kompas, $16 / 2 / 2015)$. This is so ironic knowing that tey failed to onform te law. It seems that instead of giving attention to their education quality, they only busy in commercializing their institution.

The operational violation did by such campuses above are vary, such as the violation of constitution, expired license for certain study program, illegal study program, overpopulated class, short lecture, internal dispute, double status of lecturers, or transferring students without the permission of Kopertis. This condition cannot be ignored since the quality of our universities nowadays are relatively low, proved by the small number good-accredited PTN/PTS.

Based on the data of Kemenristek Dikti 2017, from 4,300 universities in Indonesia, only 49 obtained "A" accreditation. This encourages us to choose the qualified university and it is a "must". Because it determines the eligibility of the lecture and the success in the future since universities are the door to future. Students cannot merely go to any campus and graduate, 
but also gain and develop themselves (Ahmadi, 2017:9).

Throughout the year, the amount of LPTK keeps increasing, both for PTN and PTS. The total amount of universities under the supervision of Kemenristek dikti is currently 4.525 (Republika, 10/3/2017). With such quantity, LPTK have strategic potential in producing millions of professional teacher with character. As the part of Universities, LPTK shall answer the question of which one we shall prioritize, quantity or quality.

\subsection{The Problem of temporary Teacher}

The quality and the social work dedicated by temporary teacher will never maximum without the support of adequate prosperity. Moreover, in Indonesia, there is a disparity between the civil servant-teacher and privateteacher, either in state school or private school. Kemendikbud recorded that by 2017, there are 674,775 temporary teachers in state school (Kompas, 20/3/2017). This amount is incomparable to the amount of retired teacher each year.

Temporary teachers contribute so much in educational operation and learning activity at state high school, start from elementary to high school. Without the, the teaching and learning will not go well. Even so, the appreciation towards them is still low seen from their small payment since it is only taken from Operational Aid to School Program (BOS), school committee, and local budget.

In several cities, the payment for temporary teacher has been adjusted to the minimum wages in each region. Meanwhile, in other are, their payment is very low, that is about $\mathrm{Rp} 100,000$ to $\mathrm{Rp} 500,000$. This problem could not be fixed without any system change. Even though the teachers seemed to be fine with it, but clearly they are being burdened for they are unable to fulfill their family needs. There is no way that these temporary teachers will always work for "nothing".

Kemendikbud projected that during 20162020 , there are 316,535 retired teachers or averagely 62.000 retired teacher per year. Meanwhile, the teachers that conform the standard of Teacher and Lecturer Law (UUGD) teacher in Teacher Training Program (PPG) 2005 are only 3,000-5,000 people per year.

The enactment of Civil Servant Moratorium from 2014-2019 has disrupted the ratio number of teacher. Even though there is the initiative to promote temporary teacher gradually, yet the ratio between retires teacher and promoted teacher as civil servant is still unreliable. The improvement should not only about the payment or teacher promotion, but basically about developing LPTK as teachermaker.

\subsection{Teacher Professionalism}

One of the indicators of teacher professionalism is obtaining the teaching certification from Education and Training for Teaching Profession (PLPG), Professional Teacher Training Program (PPG), and other similar programs. Unfortunately, the existing amount of such teacher is incompatible with the real condition, as in terms of quantity, we are lack of teachers. According to the data from PGRI (Indonesian Teacher's Union) in 2017, there are 155,048 redundant teachers in the whole nation. Yet if we look at the smaller scale, in school, we have insufficient permanent teacher. Based on Dapodik 2016, there are 550,604 more teachers needed in Elementary, Junior High, and Senior High School. While in Vocational High School, there are 91,000 teachers needed. After UUGD was applied in 2005 , there were $1,061,500$ teachers promoted to be permanent teacher, but $40 \%$ of them were not university graduates.

Indonesia still has lack of 282,224 Civil Servant- classroom teachers, but if search the data of non-Civil Servant classroom teachers, there will be 82,245 redundant teachers. Meanwhile, according to the Database of Higher Education (PDPT) Kemenristek dikti, there are 415 LPTKs, 37 of them are state-LPTKs and the other 378 are private LPTK, that graduates 91,247 students of Primary School Teacher Education Department. It is projected and calculated that in 2025 , there will be 444,551 graduates (Tribun, 28/4/2017). Up to these days, Indonesia still focuses on multiplying the number of graduates without elevating the quality and professionalism of teachers.

Professional teachers are urgently needed to be built in LPTK. This is because 
professional teachers are educated agents who own the ability and skill in teaching that they are able to execute their obligations. According to Nurdin (2004:20) professional teachers are those who manage to implement multidimensional relationship.

Such teachers are those who fulfill the administrative, academic, and characteristic criteria internally. Teachers can be considered professional based on two perspectives. First, based on the minimum educational background or from which university they are graduated from. Second, based on the teachers' mastery upon the subject they teach, the teaching and learning management, the ability in guiding the students, etc. In terms of educational background, the professionalism of Indonesian teachers are vary, start from the incompetent up to the competent ones (Danim, 2002:31)

Despite of the various definition of professionalism, there are actually the hierarchy of teacher professionalism that cannot be achieved in a short period of time. Semiawan (1994) in Danim (2002:31) stated that the hierarchy of educational staff is constructed as follows:

a. Professional staffs are those who have the qualifications of ,at least, university graduates or the equivalent, and has the full authority in planning, executing, and managing the teaching process. They also have the authority to guide other educational staffs with lower professional position, such as the seior teacher who guide the juniors.

b. Semi-professional staffs are those who have the qualifications of are the staffs who have the qualifications of 3 year-Diploma or the equivalents and have given the authority to teach, but still have to consult the senior staffs in doing their duties.

c. Pre-professional staffs are those who have the qualifications of are the staffs who have the qualifications of 2 year-Diploma or lower. These staffs are still in need of guidance, assessment, and management in teaching/educating.

\subsection{Quality Improvement of LPTK}

LPTK quality is the key to the creation of professional teachers. Therefore, LPTK quality should be encouraged to adjust the conditions of the era. Quality in education includes 4 aspects, including: quality of input, process, output, and outcomes. The further explanations are as follows: 1. Input of education is considered having good quality if it has been processed. 2 . Education process is considered having good quality if it is able to create active, creative and fun atmosphere. 3. Output is declared having good quality if the student learning results - in academic and nonacademic - is high as expected. 4. Outcomes declared having good quality if graduates are quickly absorbed in the world of work, getting reasonable salary, and all parties recognize the power of graduates and they feel satisfied (Juangsih, 2015: 74).

While Slamet (in Azhar (2011: 79) says that there are four fundamental efforts that must be performed to produce good quality, such as:

a. Create a win-win; not win-lose situation, among stakeholders with educational institutions. Particularly between institutional leaders and institutional staff shall create mutually beneficial conditions for each other in achieving the quality of products / services produced by educational institutions.

b. It is necessary to develop intrinsic motivation for everyone involved in the process of achieving the quality. Everyone in educational institutions shall encourage their own motivation that the results of their activities will reach a certain quality which increases continuously, especially in accordance with the needs and expectations of users.

c. Each leader shall be oriented towards longterm processes and outcomes.

d. The implementation of integrated quality management in education is not a shortterm change process.

e. In order to drive all the ability of educational institutions to achieve the certain quality, it shall develop the cooperation among parties who work to achieve the quality. Everyone must cooperate and cannot be separated from each other to produce the expected quality.

Qualified LPTK certainly will create qualified teachers. It is a definite law in the academic world. Unfortunately, the condition of LPTK in Indonesia is still ignored by the government compared to the campuses that have non-educational majors. From the budget side, 
for instance, funds for LPTK are very small compared to other campuses. Those cases are for state-LPTK, while for private-LPTK, its condition is more pathetic.

There are several solutions can be implemented. First, Kemenristek Dikti must seriously pay attention to LPTK's condition, both in terms of budget and quality of the teachers. Secondly, Kemenristek Dikti shall facilitate qualified educators and educational staff by providing S2 or S3 scholarship opportunities, both domestically and abroad. The more lecturers of doctoral graduates, the quality of graduates also becomes better.

Third, LPTK status must be clearly accredited, both public and private. Since, currently there are many "fake study programs" appeared and it would be a boomerang for graduates. If the study program is not clear, then it is better to be suspended (Ibda, 2012: 19). Therefore, only qualified LPTKs are able to produce qualified teachers.

Fourth, the high number of registrants of the Teacher Education Department each year should be responded positively by the government, especially in order to build a better and focused mapping system in order to fulfill the needs of teachers. So far there are still many complaints due to lack of teachers in certain areas. Fifth, prospective teachers have to master pedagogical, personality and social competence and mastering 8 teaching skills. Teachers are also not only required to designing and teaching, but they also have to "educate" and become second parents in school. During this time many teachers are still "teaching", not fully "educate". They are not yet educators, but still teachers. Teachers also must always improve the quality through additional lectures, seminars, training and diligently conducting research, joining scientific writing competitions and so forth. If that happens, the teachers as "Lighthouse" of education do not just become a myth.

Sixth, being a teacher is not a profession to be rich. But if you want to become rich people, then be a teacher. Those sentences have meaning that, before becoming a teacher, the students must straighten their intention to teach and educate the nation. Do not register in the teacher education department only due to money orientation. The students must arrange their mindset. It means essentially, "the teacher does not look for money, but money is actually looking for the teacher".
Students must straighten the intention that the lecture is not just looking for knowledge, titles and wealth as much as possible. The nature of college is to organize ways of thinking, changing behavior and improving the quality of life. Being an elementary school teacher is not just looking for money and certification, but it must be a tool to be a good person who seeking glory before God and mankind. Elementary school teachers are not everything, but everything can come from there.

In accordance with UUGD, teachers are professional educators with the main task of educating, teaching, guiding, directing, training, assessing and evaluating learners in early childhood education of formal education, basic education, and secondary education (UUGD 2005: 1-2). In this context, elementary school teachers, for example, must be firmly educated under S1 of PGSD and must be revolutionary. Dandan Supratman (2014) explains that elementary school teachers are the first officers to instill the character, ethics and morals. Elementary school teachers with undergraduate degree are not enough, because it only relates to academic qualification according to UUGD. If necessary, elementary school teachers must study S2 and S3. With striving awareness, all students in teacher education program should be able to find a formula in order to become revolutionary teachers and professionals in intellectual and moral fields.

The term of "knowledge is worth as much as gold" should be the motivation for the rise of education. With extensive knowledge, Indonesia can have good quality of human resources in national and international level. It cannot work optimally and systematically without the quality and equity of teachers in regions. Because, most of the time, the conversation is always about the salary of honorary teachers which is considered "non-humanist".

\subsection{Strategic Policy}

The existence of teachers cannot be maximized without the provision of LPTKs that meets SNPT. Therefore, the quality can be overcome with the number of many LPTKs, but it will not be good if LPTK is not qualified. LTPK improvement is not just technical matter of the quantity of prospective teachers. But it must be fundamental from beginning to end. 
First, the determination of curriculum and learning system in LTPK should refer to Law Number 12 Year 2012 on Higher Education. It was also adapted with Presidential Regulation no. 08 of 2012 on the Indonesian Qualification Framework (KKNI) and Minister of Research, Technology and Higher Education Regulation (Permenristekdikti) Number 44 of 2015 on National Standards of Higher Education (SNPT).

Although the campus has its own "statutes", but it must be in accordance with the spirit of "Tri Darma (Three Promises) of Higher Education". Do not let LPTK determine the curriculum "perfunctorily" and deviated from the spirit of KKNI and SNPT. Secondly, the formulation of learning systems should also refer to external aspects, ranging from challenges and global competition and the ratification of Indonesia at various conventions. Then the internal aspects of quality gaps of the relevance of graduates, a variety of qualifications, and a variety of education.

Third, the acceleration of lecturers for further study of S3 (doctorate). The number of our professors who have been professors until 2015 about 5,097 people and 75,000 doctoral people (Forlap Dikti, 2015). This number is certainly not in accordance with the number of LPTKs, compared to the developed countries such as Finland, China, Japan. So, through government and private scholarship programs, even through independent programs, LTPK shall boost lecturers for taking further study. Most lecturers who held doctoral degrees and achieve professors are dominated from science and technology, mathematics and science, and language faculty. While the ratio of doctoral lecturers in education sciences faculty is still small.

Fourth, the development of research and innovation is a key in building the nation's competitiveness. Therefore, LPTKs must boost the research in the field of education from elementary to high school level. Moreover, in 2016 Indonesia's research publications were 11,406 (Kompas, 7/3/2017). The number is far below from Malaysia which had 25 thousand. However, Ministry of Research, Technology and Higher Education (Kemenristek Dikti) is optimistic that in the future, Indonesia can occupy the top position in research publications in ASEAN
Within a year, Indonesia has only produced 6,260 research. While Malaysia has made 25,000 research, Singapore 18,000 research, and Thailand 12,000-13,000 research (Kopertis 12, 2016). The number of Indonesian research has been very few which entered Scopus, DOAJ, Google Scholar, Thomson Reuters and others. But it has been bridged by Kemenristek Dikti by digitalizing the publication of scientific journals using Science And Technology Index (Sinta).

Kemenristekdikti also prepares the instrument of Permenristekdikti Number 20 of 2017 on the Provision of Professional Lecturer Allowance and Professors Honor allowances to improve the quality and quantity of the publication of chief rector and professor. There are also Permenristekdikti Number 44 Year 2015 which specifically regulates the obligation of publication of master and doctoral students.

We hope LPTK can become ASEAN champion. If it examined, logically it can be achieved since there are two instruments of Permenristekdikti that encourage scientific publications, especially Kemenristek Dikti notes there are 151 thousands of potential research that can be published. LPTK in academic world is not everything, but as a teacher creator, LPTK is "everything"

\subsection{LPTK Strategic Role in Producing Professional Teachers}

LPTK has a strategic role in creating professional teachers. LPTK quality should be driven by qualified human resources, both from the ranks of the rector, lecturers and employees. The improvement of LPTK should be professionally and comprehensively, then thorough evaluation conducted by LPTK standardization must be accompanied with serious effort, awareness and commitment to implement it and be responsible for its implications. That must be the answer that requires serious attempts from all parties. Standardization is the starting point for providing an objective and correct direction and standards. LPTK standardization covers several things: first, institutional standardization; second, standardization of education programs; third, standardization of institutional management. 
The institutional standardization is directed to assess the qualitative feasibility of LPTK institutions. The essence is to provide an objective answer to the problem to what extent the LPTK meets the standard quality so it is necessary to implement educational programs of education personnel. The standardization of the program is directed to assess the extent to which the program presented qualitatively meets the established standards so that the program will undoubtedly have the credibility to produce qualified human resources. Management's standardization is to provide a benchmark on whether each LPTK has management systems and capabilities to ensure that institution with its programs is credibly trusted to use its function as LPTK which produces qualified output (Azhar, 2009: 9-10).

On the other hand, LPTK needs to make a breakthrough to prevent "stagnate" because the university world is a scientific world which must always be innovative. So, it must perform a number of solutions in order to produce qualified and reputable campus. First, all LPTK staff must obey UUGD and Higher Education Law. It is an obligation since currently, the existence of 'fake campuses' which are merely unconstitutional. If the initial programs are right, then the visitation / accreditation is also true

Secondly, all LPTK programs must refer to KKNI in which completed with the lecture system and others. Third, improving human resources by encouraging the academic community to study further, especially for lecturers, not only domestically but also overseas. Therefore, the opportunity to get a scholarship is currently very wide open, both opened by Kemenristekdikti and Kemenag and other institutions. Fourth, the ranks of the rectors, deans and heads of departments shall always be innovative to meet the needs of students. As leaders, lectures and its problems are always dynamic. Thus, it must be balanced with the refreshment and even reformation of campus bureaucracy.

Fifth, the quality of LPTK can be considered reputable or not is classified from the number of lecturers works. It has also been encouraged by the Regulation of Menristekdikti No. 20 of 2017 on "Provision of Professional Lecturer Allowances and Professors Honor Allowances". Inevitably, lecturers must be able to meet these demands for the sake of educational progress.

On the other hand, the community also plays significant role in guarding the development of LPTK. If necessary, there should be an good communication between the campus and the student's parents. Because, almost all parents just know the lecturer condition of their son/daughter when they are accompanying their son/daughter at the admission of new students process, while paying semester tuition fee and paying for graduation only. Therefore, it needs special and intense meeting so that the campus is close to the community.

.A qualified LPTK should start with small things. The quality here can be described from the vision-mission, curriculum, lecture system, the number of lecturers who are doctoral and professors and having achievements, both from lecturers and students. The campus academic community must also be active and technologically literate. Therefore, the quality and reputation of the campus is not only considered from the local, but now in the era of MEA, all the things are viewed from the international scale. So, the campus shall update its ranking. It can be through the University Rankings institutions, such as Times Higher Education (THE), QS World University Rankings or Webometrics Ranking of World Universities and others.

The preparation of teachers as professional educators is a mandate from Law no. Law No. 14 Year 2005 on Teachers and Lecturers, PP. 74 of 2008 about Teachers and reinforced by Law no. 12 of 2012 on Higher Education which states that professional education is higher education after undergraduate program to prepare students in seeking jobs that require special skills.

As the creator of educated people, LPTK also has a job to answer the needs of the era through the quality of graduates, meaning after graduation, the scholars are not "unemployed" and it can not be tolerated. In addition to that problem, the fundamental mission of LPTK is to produce professional teacher candidates who have been facilitated by Kemenristek Dikti by opening PPG Study Program. It should be utilized by fulfilling the specified requirements. If this plans can not be implemented now by LPTK, then LPTK can prepare for the next year. 
Because, the fate of students is depending on LPTK decision.

\section{CLONCLUSION}

Various policies have been made by the government to promote education in Indonesia by boosting the quality of LPTK and also giving LPTK opportunity to open PPG study program as a drive system to produce professional teachers. However, it would be useless if many LTPKs only look for "quantity", then it is impossible to create professional teachers who are able to answer the challenges of this millennium era.

There are several things that should be considered by LPTK in revitalizing its role and existence in producing professional teachers, these are:

1. LPTK works closely with other LPTKs to support each other's success in educational goals

2. LPTK prepares graduates who are professional in both academic and nonacademic matters.

\section{REFERENCES}

[1] Afa, Khoirul Anwar. (2017). Potret Pendidikan Indonesia. Semarang: Formaci.

[2] Ahmadi, Farid. (2017). "Menggenjot Reputasi Perguruan Tinggi". Joglosemar, March 23rd 2017. Pg.

[3] Azhar. (2009). "Kondisi LPTK sebagai Pencetak Guru yang Profesional". Jurnal Tabularasa, PPS Unimed, Vol. 6. No.1, Juni 2009. Pg. 9-10.

[4] Ibda, Hamidulloh dan Wijayanti, Dian Marta. (2014). Siapkah Saya Menjadi Guru SD Revolusioner? Depok: Kalam Nusantara.

[5] Juangsih, Juju. (2015). "Peran LPTK dalam Menghasilkan Guru yang Profesional". Jurnal Wahana Didaktika, Vol. 12. No.2 May 2014. Pg. 74.

[6] Danim, Sudarwan. (2002). Inovasi Pendidikan : dalam Upaya Peningkatan Profesionalisme Tenaga Kependidikan.Bandung: Pustaka Setia Bandung.

[7] Kemendikbud. (2017). Panduan Umum Bimbingan Teknis dan Pendampingan Pelaksanaan Kurikulum 2013 Sekolah
Dasar. Jakarta: Subdit Kurikulum, Direktorat Pembinaan Sekolah Dasar, Direktorat Jenderal Pendidikan Dasar dan Menengah Kemendikbud.

[8] ----.-. (2014). Kompetensi Dasar Sekolah Dasar (SD)/Madrasah Ibtidaiyah (MI). Jakarta: Kemendikbud.

[9] Nurdin, M. 2004. Kiat Menjadi Guru Profesional. Jogyakarta: Prismasophie.

Other Sources

[10]Peraturan Menteri Pendidikan dan Kebudayaan Republik Indonesia Nomor 160 Tahun 2014 tentang Pemberlakuan Kurikulum Tahun 2006 dan Kurikulum 2013. Jakarta: Published by Kemendikbud.

[11]Peraturan Menteri Pendidikan Nasional Nomor 16 Tahun 2007. Jakarta: Published by Kemendiknas.

[12] Peraturan Pemerintah Nomor 19 Tahun 2005 tentang Standar Nasional Pendidikan, dan Peraturan Pemerintah Nomor 74 Tahun 2008 tentang Guru. Jakarta: Published by Kemendiknas.

[13]Permendikbud Nomor 62/2013 tentang Sertifikasi Guru dalam Jabatan untuk Penataan Guru. Jakarta: Published by Kemendikbud.

[14]Peraturan Menteri Pendidikan dan Kebudayaan Republik Indonesia Nomor 4 tahun 2014 Tentang Penyesuaian Penetapan Angka Kredit Guru Pegawai Negeri Sipil dan Guru bukan Pegawai Negeri Sipil. Jakarta: Published by Kemendikbud.

[15] Pedoman Sertifikasi Kompetensi Pendidik 2004. Semarang: Published by Unnes.

[16] Surat Keputusan Bersama Lima Menteri (Menteri Pendidikan Nasional, Men PAN dan Reformasi Birokrasi, Mendagri, Menteri Keuangan, dan Menteri Agama) Nomor $\quad 05 / \mathrm{X} / \mathrm{PB} / 2011, \quad$ Nomor SPB/03/M.PAN-RB/10/2011, NOMOR 48 Tahun 2011, Nomor 158/PMK.01/2011 dan Nomor 11 Tahun 2011, Tentang Penataan dan Pemerataan Guru Pegawai Negeri Sipil. Jakarta: Published by Kemendiknas.

[17] Undang-undang Republik Indonesia Nomor 14 Tahun 2005 tentang Guru dan Dosen. 2006. Jakarta: Published by PT Armas Duta Jaya.

[18] Undang-undang Sistem Pendidikan Nasional No. 20 tahun 2003. Jakarta: Published by Kemendiknas. 